\title{
Lumen
}

Selected Proceedings from the Canadian Society for Eighteenth-Century Studies

\section{Is Sex Necessary? Criminal Conversation and Complicity in Sarah Fielding's Ophelia}

\section{Nancy Paul}

Volume 16, 1997

Freedom and Boundaries

Émancipation et frontières

URI : https://id.erudit.org/iderudit/1012444ar

DOI : https://doi.org/10.7202/1012444ar

Aller au sommaire du numéro

Éditeur(s)

Canadian Society for Eighteenth-Century Studies / Société canadienne d'étude du dix-huitième siècle

ISSN

1209-3696 (imprimé)

1927-8284 (numérique)

Découvrir la revue

Citer cet article

Paul, N. (1997). Is Sex Necessary? Criminal Conversation and Complicity in

Sarah Fielding's Ophelia. Lumen, 16, 113-129. https://doi.org/10.7202/1012444ar 


\section{Is Sex Necessary? Criminal Conversation and Complicity in Sarah Fielding's Ophelia}

In 1776 James Fordyce wrote of the civilizing influence of the conversation of ladies: 'Men will be found much the more courteous and amiable, as well as entertaining and accomplished, for their constant intercourse with a sex whom they are taught from the beginning to treat with attention and respect....' (Georgia 29). The reference to 'intercourse' in this passage is incongruous to a modern reader who associates the term with sexual rather than verbal relations. A reader in the eighteenth century encountering the word 'conversation' out of context might have experienced a similar hesitation affixing meaning; although its sense as discourse dated from at least 1560, a prominent early definition is evident from the legal use of the term 'criminal conversation' to denote illicit sexual intimacy (Georgia 252). The linguistic confounding of carnal and conversational interactions provokes comparison, even evaluation. Can one kind of intercourse be successfully substituted for the other? Along with humourist James Thurber, we might ask: Is sex necessary?

In Sarah Fielding's last novel, The History of Ophelia (1760), sex is conspicuous by its absence. The heroine falls in love with her abductor's voice, his persuasive language, but demonstrates a surprising absence of overt sexual desire for him. Early in the narrative Ophelia realizes her Lord's 'continual Conversation' has already become 'absolutely necessary to [her] Ease of Mind' (1: 89). When she is abducted by mistake and her supposed lover (she assumes Dorchester) comes to her in the dark, she is disconcerted:

The Rapidity with which he flew to me, and the Eagerness of his Embrace, astonished and startled me: I never had seen any Degree of such Familiarity in him. I was not sensible of any Impropriety in the Expressions of Affection; but without knowing a Reason for it, I was disturbed with this Address. I could not think such Violence the necessary Consequence of Love; I was as much rejoiced, I imagined, as he could be, and yet such Behaviour did not appear natural to me. (1: 104) 
What indeed is 'natural' behaviour? Ophelia can find no reason for a violent expression of affection; what does it mean to be rational? Fielding poses these questions for her readers. There is a strong satiric vein in this romance: society and its affectations are critiqued, and the assumption that women were incapable of reason is challenged. Ophelia is introduced as a wild child foundling living in paradisal isolation with her aunt. When the 'fair Savage' is brought into the urban world she responds like Gulliver to the Lilliputians, describing the antics of civilized man with an ingenuous delight and attention to detail.

Innocent she may be, but not simple; Ophelia is deceptively complex, and in her self-deception lies her complexity. Fielding's avowed aim in her often experimental writings was to explore the labyrinths of the mind. ${ }^{1}$ Ophelia professes not to understand why she has quickly come to love Dorchester better than her aunt (1:79). She represses her sexuality but learns to recover it in language; she substitutes verbal intercourse for sexual. Silence, which is identified in the first part of the novel as the space of youth and innocence, takes on new significance in the world of sexual difference. Within the construct of conversation as the prime medium of male-female communication, the ecstatic, breathless silence comes to be symbolic of the ultimate punctuation.

It is suggestive to view Ophelia as a kind of 'writing back' to Samuel Richardson's Clarissa, which Fielding greatly admired. Both novels are epistolary in form and tell the story of an abduction. Clarissa concludes with the heroine's rape and tragic death, while Ophelia ends happily; the heroine triumphantly retains her chastity and reforms her rogue admirer Dorchester into a lover worthy of marriage. Yet Fielding's novel has an undercurrent of melancholy which belies its professed romantic-comic structure, and personalizes its satiric thrust. Ophelia's long letter to 'her Ladyship' is a form of extended conversation, as the periodic intrusions of the narrator remind us. It also represents, to some extent, the rationalizing ramblings of a mind circling around its own guilt and complicity. There is a despair in Ophelia's story which will out. Patricia Meyer Spacks suggests that such an underlying tone of unhappiness is typical of epistolary fiction of the period written by women. She finds in these works a 'troubling message of despair' and 'demonstration of female ineffectuality' ('Female Epistles' 75). Even when they end in marriage, 'dreadful happenings precede the happy ending' (72).

Fielding's Remarks on Clarissa (1749) helps us to understand the author's attitude to Richardson's heroine, and thus the later construction of her own. The work is an unusual piece of literary criticism. Clarissa is the subject of conversation among 'a pretty large Assembly of mix'd Company' (4); Miss Gibson, Fielding's own representative (Remarks, 'Introduction' v), speaks on behalf of the novel and defends its heroine's 
virtue and honesty against others in the group critical of her actions. Clarissa is a woman aware of the power a husband would have over her, claims Miss Gibson, and she is thus unwilling to grant that power to one unworthy - even if she is attracted to him, as she is to Lovelace. Comparison of Clarissa and Ophelia casts the latter in a less than flattering light: although naive, Ophelia is not honest. Naturally vain, she is vulnerable to admiration and therefore corruptible; she is intelligent but not principled, and she is determined to embrace as a husband a man she knows to be a villain.

In her preface, Ophelia defends the length and level of detail of the story she tells; she defensively, wearily chastises 'her Ladyship' for what was probably a lightly extended request for 'an exact Account of every Circumstance of my Life, and even of my Thoughts.' She is surely correct in surmising that her correspondent did not expect so extensive an epistle. Ophelia herself has a need to self-construct retrospectively, to apply a shapely moral configuration to the past. ${ }^{2}$ Looking back, she sees circumstances through which she passed safely, naively, but which she now realizes were overwhelmingly dangerous to her integrity, her sanity, her virtue. It is a terrifying vision. Even more frightening, however, to our chaste, rational heroine is the shadow of belief that she might have been unconsciously complicit - that she had somehow desired the danger. The horror of this spectre keeps Ophelia's sexuality buried; it surfaces in her story through the metaphor of language, in the alternating media of silence and conversation.

\section{II}

In her discussion of relations between women in the eighteenth century, Betty Rizzo suggests that 'the problem of women's sexuality' was 'most difficult for women writers of the period to manage':

Already in the eighteenth century the concept of proper and improper sensibility conveniently divided women into the sexless good ones and the sexual bad ones. The virtuous heroines of women's novels love, and even love passionately, but they appear to save their sexuality for a proper consummation, expressing it only obliquely by fainting, hysterics, or some other intensely emotional display. (323)

Even granted that virtuous young women of the time were instructed never to shock their lovers with a sexual response, it is worth noting that Dorchester himself eventually wonders at his paragon's apparent coolness to his increasing familiarity and intimacy with her: 'I already begin to suspect that Miss Lenox sprung from another Creation, and was made 
out of some more icy Composition than the rest of Woman-Kind' (2:173). Ruth Perry argues that the very format of the epistolary novel dictates the primacy of words over action, that all the relationships are verbal, and that letter writing (as private intercourse) functions as a prelude to sexual relations (161). Perry suggests that seduction in epistolary novels written by female eighteenth-century authors is 'a matter of will power rather than desire,' 'an attempt to change another's mind': 'an actual sexual encounter is less to the point than the psychological capitulation which precedes it' (161). Ophelia's will triumphs in the end. Rather magnificently, our heroine plays the heartless gallant, leaving Dorchester in a romantic, feminine rapture, speechless with frustration and hopeless desire. He has promised her marriage, his fortune, but she is adamant:

I know not whether I could for ever have refused to comply, but happily for me, his Reason failed him, before he had sufficiently conquered mine to get my Consent; his Spirits were so oppressed, he became quite speechless, and almost senseless. I was half distracted, but as soon as he began to come out of this Fit, to avoid prolonging a Scene so difficult for me to support, I left the Room, though not without taking a kinder Farewel than seemed consistent with a Desire never to see him again, which I begged, while with Tears, I kissed his Hand. He had only Power to look up at me, with dying Eyes, swimming in Tears. Thus I left him .... (2: 238-39)

Ophelia turns the sexual tables on her lover: she teaches him the feminine art of sublimating sexual passion for spiritual (or material) gain.

But the narrative is not ultimately celebratory in tone, despite the heroine's victory. Ophelia acknowledges that a large part of her power lay in her performance. Fielding's disapproval of her heroine's theatrics might be inferred from Miss Gibson's stout defence of Clarissa from the charge that her behaviour, when she commands Lovelace to leave her, is similarly false and manipulative:

Was this like exulting in her own Understanding, and proudly (as I have heard it said) wanting to dictate to the Man she intended for a Husband? Such a woman, if I am not greatly mistaken, would not desire the Man to leave her because she saw her Soul was above him; but on the contrary, concealing from him, and disguising her Thoughts, would have set Art against Art, and been the more delighted to have drawn him in to have married her, that she might have deceived him, and enjoyed the Thoughts of her own Superiority for Life. (53)

'Such a woman' as Ophelia reveals evidence of strain in her role of wilful naivety. The split functions of heroine and consummate observer/nar- 
rator serve to aggravate her internal discord and the resulting dysfunctional quality of the entire romance. What can it mean to our determinedly blameless heroine that she matter-of-factly describes her own actions as false to her stated intention? In tears, kissing Dorchester's hand, telling him she will not have him, she yet bids her lover a 'kinder Farewell than seemed consistent with a Desire never to see him again.' Fielding's final comment on the potential for male-female communication is charged with despair.

\section{III}

In the beginning it is of course Ophelia who is speechless. Dorchester's arrival (as 'the Stranger') interrupts Ophelia and her aunt in their feminine, silent world of water, moonlight, and mirrors. Although the pair have books and writing materials with them in their isolation, Ophelia's misanthropic aunt is not inclined to allow her niece's imagination to be corrupted through reading:

The Books she had brought into Wales were chiefly Books of Divinity, and such Histories as served to enlarge and instruct the Mind of the Reader, without informing him of the existence of Vices, which a pure Imagination, untaught by Observation and Experience, cannot represent to itself. My Aunt so artfully diversified my Employments, that fond as I was of Reading, I had not perused all her little Library when I left this Solitude ... (1: 12 -13)

Into this tranquillity the sound of a human voice - a harbinger of the imminent impingement of the urban, mannered world - is so strange to the two women that they cannot recover themselves to return an answer.

Unlike Milton's Eve, Ophelia, in her introduction to sexual difference, finds her future partner's countenance 'far more beautiful then [her] own.' It soon becomes apparent that the female sphere has for some time been incomplete for our adolescent heroine. She is jealous of the easy way the Stranger speaks with her aunt, for she knows instinctively that such verbal intercourse is emblematic of adult (sexual) experience. ${ }^{3}$ Aunt keeps Dorchester up late the night of his arrival in fervent conversation. The next morning, when it is apparent to both women that the Stranger prefers Ophelia, Aunt is silenced and Ophelia triumphantly begins to converse with him: 'My Bashfulness wearing off by Degrees, during the Course of that Day, I got Courage to join in the Conversation, and, must confess, I never thought the Gift of Speech, peculiarly bestowed on Man, so great a Blessing' (1: 23). When he leaves she mourns his absence, 
finding her former amusements dull. She recreates his presence by speaking of him at every opportunity to her aunt, who in turn feels rebuffed and whose melancholic response makes Ophelia feels guilty. She tells us she was 'rendered ... silent on the Subject (1:26). Two months later Dorchester returns to abduct her, and Ophelia maintains her silence despite being roughly seized, even as her aunt 'begged, intreated, and used every Argument to prevail on him to let me go' (1: 27). In reflecting on the scene the mature Ophelia explains her failure to cry out as having been due to an inability to perceive the extent of her own danger; she was rather 'more frighted with the Terror in which I saw her [Aunt].' Further, she recalls being shocked when her aunt addresses the abductor as Dorchester, since Ophelia herself could not make out his face in the darkness, nor imagine it was the man of her dreams accosting them. ${ }^{4}$

Safely away, the self-admittedly vain Ophelia revels in her Lord's admiration. In her rage, she loses 'all Utterance' (1: 30), then 'paints' her wretchedness. Finally, in her first full speech in the text, she castigates Dorchester for tearing her from her 'dear Aunt's tender Goodness and faithful Friendship ... a Blessing nothing can equal' (1:32) - as we have seen, a representation there is reason to question and qualify. Ophelia is violently ill for a time (almost dies, she says), but gradually - owing to Dorchester's 'tender anxiety' and attention - her 'Affliction' is abated and she becomes 'capable of conversing with tolerable Ease' (1:37). And so it goes.

\section{IV}

Between 1650 and 1800 there was an outpouring in England of material urging a greater and more conscious use of conversation (Warren, 'Turning Reality Round' 66). Sarah Fielding's brother Henry claimed that in conversation 'Man stands alone' among earthly creatures. An inclination to converse with his fellows is a marker of an individual's civility:

As Conversation is a Branch of Society, it follows, that it can be proper to none who is not in his Nature social... If therefore there should be found some human Individuals of so savage a Habit, it would seem they were not adapted to Society, and consequently, not to Conversation. ... these Men live in a constant Opposition to their own Nature, and are no less Monsters than the most wanton Abortions, or extravagant Births. ${ }^{5}$

In An Essay in Defence of the Female Sex (1696), the anonymous author declares emphatically that politeness is crucial to conversation, and 
women are essential to politeness (qtd. by Klein 107). Ironically, women, traditionally consigned to the silent, were considered to excel at conversation, and were influential in its rising popularity. Writers of conduct books such as Fordyce were providing advice for men as well as women, recommending that the former seek to cultivate manners and courtesy through conversation with the latter. It has been suggested that the late eighteenth century was a highlight in the history of female-male communication. ${ }^{6}$ Arguing against the feminist contention that the containment of the domestic woman accelerated in this period, Lawrence Klein maintains that 'gendered notions of conversation and discourse played a positive role in defining the character of the public sphere in the eighteenth century and also in endorsing the female voice' (104). In a world of increasing separation of the private and public spheres - with women inhabiting the private and men circulating freely in the public - polite conversation occupied a middle zone, where refined sociability was the touchstone and where women therefore had an assured place (111).

Ophelia's inclination for conversation distinguishes her as a true heroine of her time. Closely linked with her facility and enjoyment of conversation is her rationality. Women's ability to reason was hotly contested in the eighteenth century; it was the fundamental issue for feminist writers to tackle, as the assumption that men have superior reason gave them the right to dominate over women as well as colonials (Rizzo 321). Fielding followed Jonathan Swift in having her heroine celebrate the pleasures of rational intercourse between the sexes. Katharine Rogers notes Swift's claim that the ideal for marriage was rational friendship and that sexual distinctions, as well as sexuality, should be ignored as much as possible: 'a Wise Man ... soon grows weary of acting the Lover and treating his Wife like a Mistress, but wants a reasonable Companion, and a true Friend through every Stage of his Life' (qtd. by Rogers 58). In her memoirs Swift's friend Laetitia Pilkington said that she 'would at any time give up any pleasure or gaiety for the more rational entertainment of the Dean's conversation' (59).

Throughout Ophelia's narrative, however, alongside the model of conversation exists the competing medium of silence. Associated with the feminine and the irrational, silence is primitive, the expression of inarticulate desire, paralyzing emotion, private yearning and self-indulgence. If conversation embodies the social context and signifies the means to connect effectively with the other which is not self, silence constitutes a denial of our dependence on and compassion for each other as social beings. Silence allows for the language of the eyes, that 'universal Dialect wherein even the Savage can want no instruction' (1: 16). 
When Ophelia first arrives in London she is in childlike awe at every gewgaw, and can speak 'only in Exclamations':

The Vivacity of my Sentiments made my Folly the more conspicuous.... With much Difficulty, I endeavoured to conceal my Emotions by Silence; but I found that my Eyes spoke them as strongly as my Words; and my Lord shewed me, to how little Purpose, a Person will pretend to act the Hypocrite, 'whose Thoughts are legible in the Eyes.'. . I I was again restored to my Speech, and forgave him the Entertainment he took in it. (1:127-28)

Although Ophelia finds Dorchester's admiration immensely gratifying, she resists the complete passivity which can attend to the object of the gaze. She is determined to leave behind the isolation of the irrational feminine realm, longing instead to integrate and connect, to overcome the private boundaries of the own existence. She is fiercely attracted to the male other, and conversation is the route to socially permissible sexual intimacy. Dorchester communicates with Ophelia using both speech and silence. She repeatedly mentions how his conversation delights her, and his looks of admiration comfort her, ${ }^{7}$ he says that he could converse with and look on her forever (1: 40). Ophelia's 'natural' propensity to vanity (feminine) and her faculty of reason (masculine) are thus both satisfied by this relationship.

What Ophelia does not realize is that her situation and the circumstances of her continuing conversation with Lord Dorchester might be construed by others as sexual partnership. Fielding was certainly aware of the legal term 'criminal conversation' as she used it in The Adventures of David Simple in Camilla's explanation of how the relationship between the brother and sister was perceived to be incestuous. ${ }^{8}$ Yet Ophelia seems unaware of the construction others might put on her words and actions. For example, she apparently makes no connection between her own story and that of a runaway young woman who meets secretly with her lover. Dorchester recommends to the woman that she return to her aunt, to whom she owes the duties of a child to its parent. Ophelia ingenuously claims to have been ignorant of the whole truth of the tale. Scattered throughout the narrative there are instances of foreshadowing: through recounted, parallel stories and Ophelia's attempts to explain or excuse her past actions to her correspondent. She repeatedly refers to Dorchester's real designs, of which in retrospect she is aware, and proclaims her own innocence. In punctuating her tale in this manner Ophelia is the 
consummate story-teller, for an audience which had read Richardson's Clarissa would be awaiting an impending rape. As John Price points out, the dangerous psychological fascination of rape was capitalized on by eighteenth-century novelists who 'not only raised the public's consciousness of rape as a moral crime but also helped to encourage a good deal of prurient speculation among their readers' (162). Is Ophelia's reiterated naivety believable? Lady Mary Wortley Montagu remarked to her daughter about the novel Clarissa that '[a]ny Girl that runs away with a young Fellow without intending to marry him should be carry'd to Bridewell or Bedlam the next day' (qtd. by Price 162). Ophelia allows herself to remain in a dangerous situation rather than attempt escape. In failing to write even a note of explanation to her aunt she demonstrates a lack of consideration for her guardian's distress as well as a complacent satisfaction with her own circumstances. Consciously or unconsciously, Ophelia chooses silence in this instance, evidently having convinced herself it is the language of innocence. In truth it signals her complicity.

Further, Ophelia's admitted preference for conversations with men is revealing of a flirtatiousness she does not acknowledge. Again and again she makes Dorchester jealous - through her verbal intercourse with Sir Charles Lisdale (who obviously thinks there is a sexual message in her enjoyment of his words), in her free conversation with admirers at a party of Lady Palestine's, and finally with Lord Larborough. Ophelia disclaims any deliberate coquetry:

Ought I to be ashamed of owning, that I was pleased with Sir Charles's Behaviour? Does it shew a Spirit of Coquetry to like to be approved? Surely not. I thought not of Love, nor considered him as a Lover; but my Bashfulness found great Relief from perceiving him well disposed to be pleased with what I said: His Partiality made me less careful in weighing my Words, and this Ease rendered his Conversation particularly agreeable to me. There is great Satisfaction in having the Liberty of talking Nonsense, without incurring the Contempt of our Hearers; and, perhaps, People never appear to more Advantage, than when they dare give the Reins to their Imagination and Vivacity, and leave to others the Care of being wise. (1:166)

Ophelia's vanity leads her astray. The Lisdale affair profoundly alienates Dorchester, and Ophelia first is speechless at his anger (1: 178), then distraught at the realization of the hurt she has caused him. After reading Dorchester's accusatory letter she wildly talks to herself, is rendered temporarily 'deprived on [her] Senses and gives free and unguarded Vent to [her] Distraction,' believing that she has been vilely misconstrued: 
I practice Deceit! my Ignorance of such vile Arts renders it impossible, even tho' my Disposition was not so open that I speak my thoughts as freely as they rise; and yet my Countenance expresses them before my Words can do it; and were I to pollute my tongue with a Falshood, would contradict it, and convict me of an Untruth.' (1: 185-86)

\section{VI}

Lady Mary's letter is testimony to a commonplace of the time that young ladies who ran away with men without a prospect of marriage often ended up in Bedlam. In Madness and Civilization Foucault notes a longstanding gendered criterion of madness still current in the eighteenth century: one type of madness was hysteria, the cause of which was assumed to be related to the dislocation of the womb within a woman's body (143). In the age of enlightenment, says Foucault, '[o]ften hysteria was perceived as the effect of an internal heat that spread throughout the entire body .... Was this heat not related to the amorous ardor with which hysteria was so often linked, in girls looking for husbands and in young widows who had lost theirs?' (139). Sophie von La Roche, on visiting London in 1786, declared she was 'not at all surprised to learn at the lunatic asylum of Bedlam that most of the young female inmates had been unhinged by thwarted love' (qtd. by Stone 328-29). Clarissa herself is temporarily insane at the violation she has experienced. Fielding's naming of her protagonist after the tragically deranged heroine of her admired Shakespeare is provocative, if not deliberately freighted. ${ }^{10}$ On visiting Bedlam Ophelia is struck by the injustice of confinement of wretches whose only crime is to respond excessively to their misfortunes - though in some ways, she considers, they are innocently happy in their delusions of grandeur.

It is conceivable Ophelia feels a twinge, recognizing in her writing an unconscious misconstruction of the events of her own life. By the end of the eighteenth century both hypochondria and hysteria were regarded as diseases of the (female) mind - as types of Unreason. One theorist of the time described hysteria in terms of a pathology of the imagination, as a 'disease in which women invent, exaggerate, and repeat all the various absurdities of which a disordered imagination is capable' (Joseph Raulin, qtd. in Foucault 138-139). If Ophelia does question her own rational control and authenticity, she gives no hint. However, in the closing pages of her narrative she admits 'mine was a dangerous Trial, and, I think, my Imprudence in making, deserved a Punishment rather than a Reward; which has increased my Gratitude to Heaven for a State of Happiness I by no Means merited' (2: 283). 
Ophelia's solitary ranting is not her only brush with insanity. Her imprisonment in the Marchioness's gloomy castle brings her to fear 'the Chaos of [her] own Mind' (1:270): 'I was led into a dark Room, and there left to my own Thoughts, with Subject for 'Meditation even to Madness' ' (1: 259).

Fear paints in very strong Colours; my Imagination represented to me armed Men, of most tremendous Mien and merciless Behaviour; it cloathed them like the Murderers in Macbeth .... (1: 261)

Ophelia's repressed longing for sexual intimacy manifests itself in an intense physical and emotional need for talk; she pines for the lost conversation of Lord Dorchester. Further, the resistless activity of her brain stimulates an ongoing impulse to language, with a resulting mental distress when her thoughts must be contained, stoppered up by isolation. Conversation was often prescribed in the eighteenth century 'as a guard against or prescription for the dangers of isolation' (Warren, 'Conscious Speakers' 26). When Ophelia is imprisoned she becomes so desperate to connect to others with words she talks compulsively, to those with whom she has nothing in common and who are not inclined to listen; her frustration is fuelled by the obstinate silence of Mrs. Herner. ${ }^{11} \mathrm{~A}$ visit from a neighbourhood clergyman provides some relief, as she explains with some embarrassment to her correspondent:

I have already observed, that Mr. South's Visits were agreeable, and your Ladyship will not think this so improbable, as to require any farther Assurance of it; but what will you say if I own, that the Love of Talking rendered other Company eligible, who had no other Recommendation than taking the Embargo off my Speech, and suffering me to export a few Thoughts, with which I was overstocked? Depraved Appetites are apt to have strange Consequences; the Love of talking, to those with whom we cannot converse, argues great Depravity of Mind .... (II: 26-27)

In the eighteenth century the madman stood 'as a warning that solitude nourishes deranged discourse' (Warren, 'Turning Reality Round' 65); isolation, and the inarticulate brooding of the private realm, were to be avoided as a threat to sanity. Silence was a component of the model of the chaste, closed-body woman, but for women to conform to the model could be psychologically dangerous. On the other side of the coin the link between talkativeness and licentiousness completed the circumscription of female behaviour. Women were encouraged to converse only in the context of the salons, an environment which allowed for a controlled intersection between the spheres of the public and the private, 
politics and domestic life, male and female. Ophelia steers a middle course between the dangers which lie on either side of her, between the Scylla of silence, attended by isolation and madness, and the Charybdis of social rejection and marginalization attached to excessive or inappropriate talkativeness. It is no wonder that she regards true conversation as her salvation, as her means of rendering substantial and vigorous her inner life, of connecting the two halves of her own being, and of satisfying her longing for social and sexual connectiveness. ${ }^{12}$

Ophelia is caught in the web of expectations regarding virtuous women prevalent in the eighteenth century. She cannot acknowledge any complicity in her 'dangerous Trial,' yet intuitively knows and apologizes for it. In a discussion of The Female Quixote, Warren suggests that the separation of the private and public sides of Arabella's character allows Charlotte Lennox to draw 'attention to a doubleness that forces itself upon eighteenth-century women. And since Arabella's private vision is confessed to be madness, Lennox has room to express the degree of anger latent in women as a result of the enforced split' ('Conversation of Women' 371). It is significant that a young woman's debut in society has long been referred to as her 'entry into the world' (Dulong 396) - it constitutes her admittance into the wider arena of culture and intercourse (in every sense of the word). The feminine realm of the imagination and protected innocence, the world of Ophelia and her aunt, of Arabella and her romances, does not prepare for this. Ophelia's 'coming out' is the subject of Fielding's narrative; the story is told of a young woman's movement from virginal isolation into the public world of sexual difference, and how the transition is fraught with danger. The heroine who survives the schizophrenic situation of women in the eighteenth century is not necessarily the most virtuous, or even the strongest. Rather, it is she who has the will to power, the capacity to deceive herself and to extend the deception to others, and an understanding of the danger - and exhilarating power - of language.

\section{VII}

In a recent study of women's writings and feminist critical constructs, Carla Kaplan coins the term 'erotics of talk', defining it as 'a utopian desire for the 'ideal speech situation' which pointedly does not exist and which must be imagined' (15). An erotics of talk 'may imagine what happens to ... narratives in the absence - a continued, continuing, and prolonged absence - of able and competent interlocutors'; it 'might be understood as wish fulfilment fantasy: a desire to be reassured that exchange between people is still possible, that we are not merely alone, 
speaking to ourselves, talking into the empty wind of a world from which meaningful and satisfying interrelationship has been eradicated' (15). When Ophelia refers to her 'Love of Talk' as an appetite and defends the 'Liberty of talking Nonsense,' of not always having to carefully weigh one's words, we sense Fielding's own need to communicate her thoughts with energy and delight, and her regret that direct communication is far from inherent in dialogue. Ophelia seeks an ideal listener, desiring with sexual intensity the 'ideal speech situation' of 'true Conversation' unimaginably possible between man and woman. Dorchester represents for her the potential for perfect communion, but her expectations are ironic, for he pays even her first words no heed, ignoring her plea to be returned to her aunt:

... the Excess of my Sorrow and Despair, made me eloquent; I beseeched, as a Favour, what without the highest Cruelty and Injustice could not be denied me ... I painted my Wretchedness in such strong Colours, that I at last became dumb with Horror at the melancholy Prospect; but yet, so little did it avail that I could not obtain one flattering Hope of being carried back. (1: 30-31)

In time Ophelia learns to adapt her discourse to be more pleasing to her lover; she reports that she 'became able to converse with Ease, and ceased Reproaches, which might exasperate; but I had, by melancholy Experience, found them unavailing' (1: 53).

The epistolary form suited Fielding's purpose of revealing the complexities of human personality, for the character could be read as choosing her own words, describing her own experience. As she and Jane Collier explained in their introduction to The Cry, an ambitious work that has been described as 'an unusual psychological drama in which the protagonists reveal their private thoughts through an extended dialogue with an assembly of allegorical characters representing truth and error' (Johnson 15), motivation is more interesting and important than action:

The motives to actions, and the inward turns of mind, seem in our opinion more necessary to be known than the actions themselves; and much rather would we chuse that our reader should clearly understand what our principal actors think, than what they do. To answer both these purposes, the method of making the principal character the speaker seems the best calculated. . . (17)

Fielding chose to have only her heroine's voice heard in her last novel. In The Cry there is dialogue and conversation, but in Ophelia, despite the opportunity to provide an exchange of letters between correspondents, we are given only one side of the story. The compulsive insistency of Ophelia's monologue bespeaks of a need to be heard 'in the absence... 
of able and competent interlocutors' and 'might be understood as wish fulfilment fantasy: a desire to be reassured that exchange between people is possible.' Fielding the social critic and Fielding the psychologist practiced an erotics of talk to probe the affectations and layers of deceit which mask the individual from herself and shroud human relations. As Caplan comments:

The woman narrator who longs for an ideal respondent who never comes or who finds that respondent under only the most limited and temporary circumstances, holds a critical mirror up to the failures of her fictional world and the reader's world as well. Such mirroring says, of both the private and the public sphere, that 'it does not have to be this way, it could be otherwise.' (15)

\section{NANCY PAUL \\ Queen's University}

\section{Notes}

1 Henry Fielding comments in his preface to The Adventures of David Simple that the Merit of this Work consists in a vast Penetration into human Nature, a deep and profound Discernment of all the Mazes, Windings and Labyrinths, which perplex the Heart of Man to such a degree, that he is himself often incapable of seeing through them ...' (5). In the introduction to The Cry, co-authors Sarah Fielding and Jane Collier describe their purpose: 'Thoroughly to unfold the labyrinths of the human mind, is an arduous task; and notwithstanding the many skilful and penetrating strokes which are to be found in the best authors, there seem yet to remain some intricate and unopen'd recesses in the heart of man' (14).

2 Sarah Fielding's use of the discovered manuscript form for The History of Ophelia allows her to tap into the particular rhetoric and atmosphere of autobiography. In Imagining a Self, Spacks remarks that eighteenth-century autobiographies 'sound different from their novelistic counterparts sentence by sentence because they employ by and large a different rhetoric and a different narrative atmosphere. Autobiographies - even the informal kind created by journals - rely on a rhetoric of explanation, shading often toward self-justification' (313). For an interesting discussion of Fielding's experimental use of fictional autobiography, see Christopher Johnson's introduction to The Lives of Cleopatra and Octavia .

3 Spacks contends that sexual competitiveness 'informs the relations of mothers and daughters' in the eighteenth century ('Always at Variance' 19). In general, the absence of mothers in Fielding's writing is striking; in their stead are a number of wicked stepmothers and maiden / disillusioned aunts. Mrs. Bilson in The History of the Countess of Dellwyn (1759) is a significant exception. Although Ophelia's relationship with her aunt simulates the daughter / mother bond, we perhaps allow her more autonomy because the tie is less compelling. The prominence of orphans in eighteenth-century literature has been examined by W. Austin 
Flanders, who notes that the orphan Arabella, heroine of The Female Quixote, is able to 'pursue her quixotism freely' (136). Flanders suggests that the 'kindly uncle' figure puts forward an 'alternative mode of kinship organization' reminiscent of matrilineal societies.

4 Later in the narrative, Ophelia remarks on 'the Schrillness of her Voice, or Sharpness of her Tongue, a Woman's only Weapons' (I: 105), and when she is imprisoned by the Marchioness she is 'conscious that the Shrilness of a female Voice must be almost as useful in populous Streets as a Weapon of Defence' (I: 258). We might conclude that screaming is the 'learned response' of the experienced woman, that submissive silence in a young girl is 'natural'; or, alternatively, that Ophelia chose to be silent during the abduction just as she deliberately witheld her words from her aunt, who had by that time become in her mind at once sexual rival and outmoded companion, no longer pleasurable as a partner in conversation.

5 'An Essay on Conversation' (121-22). I suspect that Sarah and Henry were in accord, that neither would have promoted the isolation of Wales as a utopian alternative to London. In Ophelia, Wales is a place for rest, retreat, and recuperation - not for permanent occupation. Further, it is the location of (Ophelia's) childhood and thus signifies transition. Despite these qualifications however it is arguable Fielding felt some nostalgia for a mythical time and place where honest men and women deal directly with one another.

6 Georgia wonders if in modern society 'something has been lost. It seems that today, men and women compete, or copulate, but they no longer converse .... Perhaps the eighteenth century, the golden age of conversation, was the one age in which women's communicative style prevailed' (255). Elizabeth Kraft refutes any suggestion that women of the period were empowered as speakers: 'Politically they were nonexistent, and even socially they were insignificant; for, be it ungoverned scandal or stylized decorum, the talk of women was not talk of significance or even signification. Theirs was, in a very real sense, a world of silence' (90).

7 For example: 'I soon forgot the Uneasiness I had undergone; Lord Dorchester's Conversation banished every painful Thought, and the Pleasure he seemed to have received from my Appearance, recompenced me for what I had suffered for it' (I: 150).

8 Camilla's step-mother Livia reports to her father of discovering 'a criminal Conversation between your Son and Daughter' (162). Camilla tells also of how her aunt denounced the pair to their faces, in a fury that they would 'make her accessary to our wicked Conversation with each other' (160).

9 Similarly, when Dorchester says to his servants that he is 'not at home' to Ophelia when she returns from her captivity at Trente's castle, she is temporarily deprived of her senses: 'As soon as he spoke, I exclaimed with the Eagerness of Distraction, 'I hear, I hear his Voice! Why do you refuse to let me see him?' and endeavoured to force my Way into the Room where he was, but the Servants stopped me, and held me fast. This was not long necessary; for his Words more effectually deprived me of the Power of Motion, and for some time afforded me Relief, by reducing me to, almost, a total Insensibility.' (2: 80)

10 Ophelia Lenox's last name as well as her first can be read as significant. The Female Quixote by Charlotte Lennox was published only a few years before 
Ophelia appeared. Both Arabella and Ophelia misconstrue their surroundings because of a dominant idealism framing their perceptions.

11 She begs of the Marchioness that if she is 'still to live with Mutes,' she needs at the very least a book. But while the melodrama of Macbeth inspires her with horror at her own situation, language - written or spoken - provides a grounding and extension for her wandering, isolated mind.

12 See Peter Stallybrass for discussion of traditional associations of closure with feminine purity. Women were seen to be naturally grotesque; the wagging tongue of a talkative woman was regarded as emblematic of a loose morality. Silence, the closed mouth, was seen to be a sign of chastity. Ophelia expresses disgust at the old woman who acts the part of the bawd for a runaway pair of lovers, describing her as immensely fat, a 'mighty Load of Flesh,' garrulous, altogether grotesque (I: 99-106). In this instance she would seem to be fashioning herself as the classical closed-body female in contradistinction to this open-mouthed, overflowing creature emblematic of excess and wantonness.

\section{Works Cited}

Dulong, Claude. 'From Conversation to Creation.' A History of Women in the West. Volume III: Renaissance and Enlightenment Paradoxes. Ed. Natalie Zemon Davis and Arlette Farge. Cambridge and London: Belknap P of Harvard UP, 1993. 395-419.

Fielding, Henry. 'An Essay on Conversation.' Miscellanies by Henry Fielding, Esq. Vol. 1. 1743. Ed. Henry Knight Miller. London: Wesleyan UP, 1972. UMI Facsimile Reprint 1994. 119-152.

Fielding, Sarah. The Adventures of David Simple. 1744. Ed. Malcolm Kelsall. Oxford: Oxford UP, 1969.

. The History of the Countess of Dellwyn. 1759. Facsimile. New York: Garland Publishing, 1974.

. The Cry. 1749. Intro. Mary Anne Schofield. Delmar, New York: Scholars' Facsimiles \& Reprints, 1986.

. The History of Ophelia. 1760. Facsimile Reprint. New York: Garland, 1974.

The Lives of Cleopatra and Octavia. 1757. Ed. Christopher D. Johnson. London and Toronto: Associated UP, 1994.

. Remarks on Clarissa. 1749. Intro. Peter Sabor. Augustan Reprint Society. Los Angeles: U of California P, 1985.

Flanders, W. Austin. Structures of Experience: History, Society, and Personal Life in the Eighteenth-Century British Novel. Columbia: U of South Carolina P, 1984.

Foucault, Michel. Madness and Civilization: A History of Insanity in the Age of Reason. 1961. Trans. Richard Howard. New York: Vintage, 1988.

Georgia, Jennifer. 'The Joys of Social Intercourse: Men, Women, and Conversation in the Eighteenth Century.' Compendious Conversations: The Method of Dialogue in the Early Enlightenment. Ed. Kevin L. Cope. Frankfurt: Peter Lang, 1992. 249-256. 
Kaplan, Carla. The Erotics of Talk: Women's Writing and Feminist Paradigms. Oxford and New York: Oxford UP, 1996.

Klein, Lawrence E. 'Gender, Conversation and the Public Sphere in Early EighteenthCentury England.' Textuality and Sexuality: Reading Theories and Practices. Ed. Judith Still and Michael Worton. Manchester and New York: Manchester UP, 1993. 100-115.

Kraft, Elizabeth. Character and Consciousness in Eighteenth-Century Comic Fiction. Athens: U of Georgia P, 1992.

Lennox, Charlotte. The Female Quixote. 1752. London: Pandora, 1986.

Perry, Ruth. Women, Letters, and the Novel. New York: AMS Press, 1980.

Porter, Roy. 'Mixed Feelings: The Enlightenment and Sexuality in Eighteenth-Century Britain.' Sexuality in Eighteenth-Century Britain. Ed. Paul-Gabriel Boucé. Manchester: Manchester UP, 1982. 1-27.

Price, John Valdimir. 'Patterns of Sexual Behaviour in Some Eighteenth-Century Novels.' Boucé. 159-175.

Rizzo, Betty. Companions Without Vows: Relationships Among Eighteenth-Century British Women. Athens and London: U of Georgia P, 1994.

Rogers, Katherine M. Feminism in Eighteenth-Century England. Brighton: Harvester Press, 1982.

Spacks, Patria Meyer. "Always at Variance:" Politics of Eighteenth-Century Adolescence.' A Distant Prospect: Eighteenth-Century Views of Childhood. Papers read at a Clark Library Seminar by P.M. Spacks and W.B. Camochan. Los Angeles: Clark Memorial Library, U of California, 1982. 3-24.

. 'Female Resources: Epistles, Plot, and Power.' Writing the Female Voice: Essays on Epistolary Literature. Ed. Elizabeth C. Goldsmith. Boston: Northeastern UP, 1989. 63-76.

. Imagining a Self: Autobiography and Novel in Eighteenth-Century England. Cambridge: Harvard UP, 1976.

Stallybrass, Peter. 'Patriarchal Territories: The Body Enclosed.' Rewriting the Renaissance: The Discourses of Sexual Difference in Early Modern Europe. Ed. Margaret W. Ferguson, Maureen Quilligan, and Nancy J. Vickers. Chicago: U of Chicago P, 1986. 123-142.

Stone, Lawrence. The Family, Sex and Marriage in England 1500-1800. New York: Harper \& Row, 1977.

Warren, Leland E. 'The Conscious Speakers: Sensibility and the Art of Conversation Considered.' Sensibility in Transformation: Creative Resistance to Sentiment from the Augustans to the Romantics. Ed. Syndy McMillen Conger. London and Toronto: Associated UP, 1990. 25-42.

. 'Of the Conversation of Women: The Female Quixote and the Dream of Perfection.' Studies in Eighteenth-Century Culture 11 (1982): 367-380.

. 'Turning Reality Round Together: Guides to Conversation in Eighteenth-Century England.' Eighteenth-Century Life 8.3 (1983): 65-87. 